University of Nebraska - Lincoln

DigitalCommons@University of Nebraska - Lincoln

Faculty Publications from the Harold W. Manter Laboratory of Parasitology

4-1995

\title{
Phylogenetic Relationships of the Genera of the Pronocephalidae Looss, 1902 (Digenea: Paramphistomiformes)
}

Gerardo Pérez Ponce de León

Universidad Nacional Autónoma de México, ppdleon@servidor.unam.mx

Daniel R. Brooks

University of Toronto,dnlbrooks@gmail.com

Follow this and additional works at: https://digitalcommons.unl.edu/parasitologyfacpubs

Part of the Parasitology Commons

Pérez Ponce de León, Gerardo and Brooks, Daniel R., "Phylogenetic Relationships of the Genera of the Pronocephalidae Looss, 1902 (Digenea: Paramphistomiformes)" (1995). Faculty Publications from the Harold W. Manter Laboratory of Parasitology. 274.

https://digitalcommons.unl.edu/parasitologyfacpubs/274

This Article is brought to you for free and open access by the Parasitology, Harold W. Manter Laboratory of at DigitalCommons@University of Nebraska - Lincoln. It has been accepted for inclusion in Faculty Publications from the Harold W. Manter Laboratory of Parasitology by an authorized administrator of DigitalCommons@University of Nebraska - Lincoln. 


\title{
PHYLOGENETIC RELATIONSHIPS OF THE GENERA OF THE PRONOCEPHALIDAE LOOSS, 1902 (DIGENEA: PARAMPHISTOMIFORMES)
}

\author{
Gerardo Pérez Ponce de León and Daniel R. Brooks* \\ Instituto de Biología, Universidad Nacional Autónoma de México, México, D.F. Apartado Postal 70-153 C.P. 04510, México
}

\begin{abstract}
Quantitative phylogenetic analysis of 20 nominal genera of the Pronocephalidae based on 47 morphological transformation series produced 6 equally parsimonious trees, each with a consistency index of $77.8 \%$. All trees agree that Adenogaster is the sister group to the rest of the pronocephalids, and a new subfamily is proposed for it. The Pronocephalinae comprises Pronocephalus, Ruicephalus, Neopronocephalus, Macravestibulum, Choanophorus, Cetiosaccus, and Metacetabulum. The Charaxicephalinae comprises Charaxicephalus, Desmogonius, Diaschistorchis, Pleurogonius, Iguanacola, Renigonius, Parapleurogonius, Himasomum, Pyelosomum, Cricocephalus, Barisomum, and Pseudobarisomum. An amended diagnosis for Himasomum is presented. The trees differ only in the placements of Pleurogonius, Renigonius + Parapleurogonius, Iguanacola, and Himasomum relative to each other. Parapronocephalum and Notocotyloides are members of the clade containing the Notocotylidae. The phylogenetic tree supports interpretations of 3-4 transitions from marine to freshwater turtles, 3 host switches from marine turtles to the Galapagos marine iguana and 3 from marine turtles to the French angelfish, and widespread host switching among marine chelonians. No switches to non-chelonian hosts coincide with transitions from marine to freshwater.
\end{abstract}

Marine turtles host a diverse array of helminth parasites, dominated by members of the digenean family Pronocephalidae Looss, 1902. Looss (1901) established the family for monostomous digeneans with cephalic collars inhabiting marine turtles, particularly Chelonia mydas (L.). Species allocated to this family include parasites of marine fish, iguanas, birds, and freshwater turtles. Classification of the Pronocephalidae has been unstable. Price (1931) recognized 3 subfamilies: Opisthoporinae Price, 1931 for Opisthoporus aspidonectes (MacCallum, 1917) Fukui, 1931 (=Teloporia aspidonectes); Charaxicephalinae Price, 1931, including Charaxicephalus Looss, 1901 and Desmogonius Stephens, 1911 ; and Pronocephalinae Looss, 1902 including Pronocephalus Looss, 1899, Cricocephalus Looss, 1899, Pyelosomum Looss, 1899, Adenogaster Looss, 1901, Glyphicephalus Looss, 1901, Pleurogonius Looss, 1901, Epibathra Looss, 1902, Barisomum Linton, 1910 (including Himasomum Linton, 1931), Diaschistorchis Johnston, 1913 (which Price synonymized with Wilderia Pratt, 1914 and Synechorchis Barker, 1922), and Astrorchis Poche, 1926.

Mehra (1932) added the Hippocrepinae Mehra, 1932 for Hippocrepis Travasos, 1922 and the Neopronocephalinae Mehra, 1932 for Neopronocephalus Mehra, 1932, placed Macravestibulum Mackin, 1930 in the Pronocephalinae, and transferred Diaschistorchis to the Charaxicephalinae. Ruiz (1946) synonymized the Notocotylidae and Pronocephalidae, recognizing 7 subfamilies: Notocotylinae Lühe, 1909; Nudacotylinae Barker, 1916; Opisthotrematinae Poche, 1926; Pronocephalinae, including Pronocephalus, Cricocephalus, Glyphicephalus, Epibathra, Pyelosomum, Adenogaster, Teloporia Fukui, 1933, Iguanacola Gilbert, 1938, and Renigonius Mehra, 1939; Charaxicephalinae, including Charaxicephalus, Desmogonius, and Diaschistorchis; Neopronocephalinae, including Neopronocephalus; and Choanophorinae Caballero, 1942, including Choanophorus Caballero, 1942, Macravestibulum, Metacetabulum Teixeira de Freitas and Lent, 1938, and Cetiosaccus Gilbert, 1938.

Received 13 April 1994; revised 19 October 1994; accepted 19 October 1994.

* Department of Zoology, University of Toronto, Toronto, Ontario, Canada M5S 1A1.
Yamaguti (1958) recognized the superfamily Notocotyloidea Kossack, 1911 comprising the Notocotylidae, Nudacotylidae, Opisthotrematidae, and Pronocephalidae. Within the Pronocephalidae, he recognized 10 subfamilies: Choanoporinae for Choanophorus, Metacetabulinae Yamaguti, 1958 for Metacetabulum, Cetiosaccinae Yamaguti, 1958 for Cetiosaccus, Macravestibulinae Yamaguti, 1958 for Macravestibulum, Teloporiinae Yamaguti, 1958 for Teloporia, Diaschistorchiinae Yamaguti, 1958 for Diaschistorchis, Charaxicephalinae for Charaxicephalus, Desmogoniinae Yamaguti, 1958 for Desmogonius, Neopronocephalinae for Neopronocephalus, and Pronocephalinae for Pronocephalus, Cricocephalus, Pyelosomum, Glyphicephalus, Epibathra, Adenogaster, Barisomum, Iguanacola, Renigonius, Medioporus Oguro, 1936, Myosaccus Gilbert, 1938, and Ruicephalus Skrjabin, 1955. Yamaguti (1971) added Pseudobarisomum Siddiqi and Cable, 1960 and Neocricocephalus Gupta, 1962 to the Pronocephalinae.

Since 1971, 6 genera, 5 of them monotypic, have been described: Paradenogaster Fischthal and Kuntz, 1975, Rameshwarotrema Rao, 1975, Parapleurogonius Sullivan, 1976, Charaxicephaloides Groschaft and Tenora, 1978, Raogaster Groschaft and Tenora, 1981, and Cortinasoma Oshmann and Zharikova, 1984. The family thus comprises approximately 80 nominal species allocated to approximately 32 genera (22 species have been placed in Pleurogonius) in 10 subfamilies.

We present herein the first phylogenetic systematic analysis of supraspecific taxa comprising the Pronocephalidae.

\section{MATERIALS AND METHODS}

\section{Specimens examined}

We examined available published accounts and the following specimens (accession numbers follow species names, number of specimens examined is in parentheses): CHIBUNAM (Colección Helmintologica del Instituto de Biología de la Universidad Nacional Autónoma de México, México City, México): Parapronocephalum symmetricum: 22418 (1); Adenogaster serialis: 217-12 (20), 233-9 (1), 212-1 (1), 225-13 (5); Pleurogonius sindhi: 213-5 (1); Pleurogonius americanus: 243-7 (2); Pleurogonius grocotti: 212-8 (1); Pleurogonius lobatus: 250-11 (5); 21 3-6 (7); Pleurogonius linearis: 32-6 (1); Pyelosomum cochlear: 233-10 (6), 212-11 (1); Pyelosomum posterorchis: 213-4 (1); Pyelosomum renicapite (=Astrorchis r.): 250-12 (8); Cricocephalus albus: 212-13 (7), 234-16 (1); Barisomum erubescens: 234-15 (4); Pronocephalus trigonocephalus: 213-3 (1); Choanophorus rovirosai: 19-9 (3), 217-17 (7). UNSMHWML 
(University of Nebraska State Museum, Division of Parasitology, Harold W. Manter Laboratory, Lincoln, Nebraska, U.S.A.): Pleurogonius malaclemys: 23753 (7); Pleurogonius trigonocephalus: 1701 (5); Glyphicephalus candidulus (=Pleurogonius candidulus and Barisomum candidulus); 157 (10), 158 (7), 123913 (5), 123914 (2), 123915 (2), 123916 (2), 124287 (1); Renigonius cuorensis: 20867 (1); Parapleurogonius brevicaecum: 20865 (1); Pyelosomum renicapite (=Astrorchis $r$.): 1700 (1); Pyelosomum amblyrhynchi (=Myosaccus a.): 1702 (2); Cricocephalus albus: 1711 (3); Charaxicephalus robustus: 1707 (1); Desmogonius desmogonius: 874 (15); Diaschistorchis multitesticularis: 20864 (1); Neopronocephalus orientalis: 20866 (3); Macravestibulum obtusicaudatum: 1706 (1), 22471 (3). USNMHC (United States National Museum Helminthological Collection, Beltsville, Maryland, U.S.A.): Pleurogonius puertoricensis: 73319 (2); Pleurogonius laterouterus: 73317 (5); Pleurogonius longuisculus: 9658 (3); $P$. linearis: 9653 (3), 73399 (9); $P$. malaclemys: 39052 (1); P. trigonocephalus: 9660 (3), 73340 (1); Parapleurogonius brevicaecum: 74052 (7); Iguanacola navicularis: 43401 (4); P. cochlear: 9665 (1); P. posterorchis: 73331 (2); Pyelosomum longicaecum: 8910 (1); P. renicapite (=Astrorchis r.): 74860 (1); Pseudobarisomum holacanthi: 39310 (1); Barisomum pomacanthi (=Pleurogonius p.): 8087 (1), 8088 (3), 8089 (1), 8090 (1), 8091 (1); C. robustus: 9619 (2); Cetiosaccus galapagensis: 9215 (1); Metacetabulum invaginatum: 73333 (4); Teloporia aspidonectes: 61205 (1); Paradenogaster self: 73009, 73010, $73011(10)$.

\section{Taxa recognized}

We used 20 of the nominal genera as terminal taxa. Ruiz (1946) considered Epibathra, Myosaccus, and Astrorchis as synonyms of Pyelosomum; we concur, and a species-level analysis of the genus (Pérez Ponce de Léon and Brooks, 1995) corroborates this decision. We found no consistent basis on which to separate Pleurogonius, Glyphicephalus solidus Looss, 1901 (the type species of Glyphicephalus), and Medioporus, so we have grouped them together as Pleurogonius. By contrast, Himasomum Linton, 1910, established for Himasomum candidulum Linton, 1910, was considered a synonym of Barisomum by Price (1931) and Yamaguti $(1958,1971)$, of Pleurogonius by Ruiz (1946) and Manter (1947) and of Glyphicephalus by Siddiqi and Cable (1960). In our study, $H$. candidulum and Glyphicephalus lobatus Looss, 1901 form a group distinct from Pleurogonius (including G. solidus) and Barisomum, so we consider Himasomum Linton, 1910 valid (see amended diagnosis below).

We did not use Teloporia Fukui, 1933, Neocricocephalus Gupta, 1962, Paradenogaster Fischthal and Kuntz, 1975, Rameshwarotrema Rao, 1975, Charaxicephaloides Groschaft and Tenora, 1978, Raogaster Groschaft and Tenora, 1981, or Cortinasoma Oshmarin and Zharikova, 1984 as separate taxa. Teloporia was proposed by Fukui (1933) for specimens described by MacCallum (1921) as Paramphistomum aspidonectes and transferred to Opisthoporus by Fukui (1929). Our examination of specimens deposited in the United States National Helminthological Collection convinced us that Teloporia lacks the cephalic collar characteristic of pronocephalids and that the arrangement of gonads and the structure of the terminal genitalia preclude its inclusion in Pronocephalidae. Neocricocephalus, established for Neocricocephalus vitallani from C. mydas from an unnamed locality in the Caribbean Sea (Gupta, 1962), purportedly possesses a muscular pharynx and lacks an esophagus. Because no other monostomes have a pharynx or lack an esophagus, and because many pronocephalids have a muscular esophagus or esophageal bulb, we are uncertain about the description of this material. Gupta did not compare the new species with the features that are diagnostic for Cricocephalus, and we are unable to discern any substantive differences between the 2 taxa. Finally, there is no indication in the publication that any type specimens were designated or deposited in any museum collection. Rameshwarotrema was proposed for 2 species described from 27 specimens collected in $C$. mydas from India (Rao, 1975). There is no evidence that type material was deposited for these species, and the original descriptions provide insufficient information to distinguish the proposed species or genus from a number of previously described taxa. Illustrations accompanying the original descriptions suggest specimens that have been excessively flattened, perhaps accounting for the "extracecal uterine loops" suggested to be diagnostic for the genus, but lacking in all other pronocephalids. Charaxicephaloides polyorchis in C. mydas from Cuba differs from
Charaxicephalus by having testes arranged in irregular double rows and not separated by uterine loops (Groschaft and Tenora, 1978), but we have been unable to obtain specimens. Based on the characters we have used, Charaxicephaloides would be the sister species of Charaxicephalus, and because it is monotypic, treating both taxa as a single genus should not affect the phylogenetic analysis. Groschaft and Tenora (1981) proposed Raogaster for the species described by Rao (1975) as Adenogaster indica in $C$. mydas from India, based on a single specimen that we have been unable to locate. We can discern no significant differences between the specimen upon which $A$. indica was based and Adenogaster serialis, a cosmopolitan species inhabiting $C$. mydas throughout the world. Paradenogaster was proposed for Paradenogaster selfi in the freshwater turtles Ocadia sinensis and Geoclemys reevesi from Taiwan (Fischthal and Kuntz, 1975). Cortinasoma was proposed for Cortinasoma ocadiae, in Ocadia quadriocellata from Vietnam (Oshmarin and Zharikova, 1984). Both species resemble Adenogaster by having ventral glands but are distinctive in lacking cecal diverticula (the plesiomorphic condition for character 5) and in having 2 polar filaments on each egg (the plesiomorphic condition for character 10). Paradenogaster selfi is further described as having a unipartite cirrus sac with an internal seminal vesicle. The holotype (USNM Helm. Coll. no. 73009) and paratypes (USNM Helm. Coll. no. 73010, 73011) of $P$. selfi exhibit cirrus sacs containing a vesiculate pars prostatica, elongate ductus Caballeroi (see character 47, below), and cirrus, similar to Adenogaster. Cortinasoma ocadiae is described as having very small rather than relatively large vitelline follicles (an autapomorphic condition); otherwise, it does not differ markedly from Paradenogaster. We have been unable to obtain specimens of $C$. ocadiae, so we are uncertain about the status of the ductus Caballeroi in that species. Based on the characters presented in the descriptions and those that we could confirm by examining specimens, we consider Cortinasoma a junior synonym of Paradenogaster. Furthermore, the 2 characters distinguishing Paradenogaster, with 2 species, from Adenogaster, which is monotypic, are plesiomorphies there is therefore no basis for recognizing more than a single genus for the 3 species. We thus consider Paradenogaster a synonym of Adenogaster.

\section{Analyses performed}

Phylogenetic analyses were performed using phylogenetic systematics (Hennig, 1966; Wiley, 1981; Brooks and McLennan, 1991; Wiley et al., 1991). Results were confirmed using the PAUP (phylogenetic analysis using parsimony) computer program version 3.1.1 (Swofford, 1993), run on a Macintosh IIX computer. The following options were examined: Characters: All unordered, or multistate characters unordered; outgroups: Deuterobarididae only, Deuterobarididae + Notocotylidae, Deuterobarididae + Notocotylidae + Parapronocephalum; optimization: Acctran, Deltran; tree-building algorithm: heuristic search/branch swapping, branch and bound.

\section{Character argumentation}

Phylogenetic systematic analyses (Brooks et al., 1985, 1989; Brooks and McLennan, 1993a) have placed Notocotylidae and Pronocephalidae as sister groups at the terminal portion of the Paramphistomiformes. Their closest relatives, based on absence of a ventral sucker and the possession of ventral body glands, appear to be the Deuterobaridinae in the paraphyletic Microscaphidiidae.

Two monotypic genera, Parapronocephalum Belopol'skaia, 1952 and Notocotyloides Dollfus, 1966, have been problematic. Yamaguti (1958) listed Parapronocephalum as a member of the Notocotylidae (Yamaguti, 1958: 791) and of the Pronocephalidae (Yamaguti, 1958: 976). Later, Yamaguti (1971) placed Parapronocephalum in the Pronocephalidae and Notocotyloides in the Notocotylidae. Both species possess collars surrounding the oral sucker and inhabit shorebirds. All analyses we performed, including those in which we placed Parapronocephalum as a member of the ingroup and asked PAUP to try to force the ingroup to be monophyletic, placed Parapronocephalum and Notocotyloides as sister groups forming a clade that is the sister group of the Notocotylidae. Therefore, the notocotylids and Parapronocephalum plus Notocotyloides served as the primary outgroups and the deuterobaridines as a paraphyletic secondary outgroup. Unless stated otherwise, all outgroups agreed on the plesiomorphic condition. We identified the following characters 
(see Table I), and their states, for use in phylogenetic analysis; character argumentation for each character follows Wiley et al. (1991):

1) Distribution of vitelline follicles. The plesiomorphic condition is vitelline follicles extending along the lateral (extracecal) margins of the body from the level of the anterior margin of the testes to near the level of the cirrus sac (0). In Ruicephalus, Metacetabulum, Cetiosaccus, Neopronocephalus, Macravestibulum, and Choanophorus, the vitellaria are restricted to near the testicular area (1).

2) Location of testes in body. Notocotylids, Notocotyloides and Parapronocephalum, like most species of pronocephalids, have testes located very close to the posterior end of the body (0). Charaxicephalus, Desmogonius, and Diaschistorchis have testes fragmented into relatively large follicles distributed roughly linearly from near the posterior end of the body to as far anteriorly as midbody (1). Pronocephalus, Ruicephalus, Metacetabulum, Cetiosaccus, Neopronocephalus, Macravestibulum, and Choanophorus have testes located in the posterior $1 / 3$ of the body, but some distance from the posterior end (2).

3) Location of testes with respect to the ceca. Notocotylids and $\mathrm{No}$ tocotyloides, like most species of pronocephalids, have extracecal testes (0). Parapronocephalum, Pronocephalus, Ruicephalus, Metacetabulum, Cetiosaccus, Neopronocephalus, Macravestibulum, and Choanophorus have intercecal testes (1); this trait is characteristic of many microscaphidiids and paramphistomids, the second-level outgroups, but is coded as apomorphic for the pronocephalids using the alternating outgroup rule (Wiley et al., 1991).

4) Location of Mehlis' gland with respect to ovary. Deuterobarids and most pronocephalids exhibit postovarian Mehlis' glands (0). Notocotylids and Pronocephalum exhibit preovarian Mehlis' glands (1), an apparent synapomorphy for those 2 groups. Desmogonius, Adenogaster, and Cricocephalus are characterized by Mehlis' glands located laterally to the ovary (2). Two species of Pyelosomum also exhibit lateral Mehlis' glands, but this is a derived condition within the genus (Pérez Ponce de León and Brooks, 1995).

5) Cecal diverticula. We have observed 7 different cecal morphologies (Fig. 1). The plesiomorphic condition is that in which the ceca are smooth-walled throughout their entire length (0); this condition occurs in members of Parapleurogonius, Ruicephalus, Cetiosaccus, Metacetabulum, and Neopronocephalus, and in some species of Pleurogonius and Adenogaster. Derived conditions include: ceca with irregular diverticula in anterior portions, found in Parapronocephalum, Iguanacola, some members of Pleurogonius, 1 species of Renigonius, Macravestibulum, and Choanophorus (1); ceca with irregular diverticula throughout their length, found in Pronocephalus, Diaschistorchis, the second species of Renigonius, Pyelosomum, and Pseudobarisomum (2); ceca with regular diverticula spaced equally on the medial and lateral surfaces of the ceca, found in Charaxicephalus (3); ceca with regular diverticula found only on medial surface of ceca, found in Adenogaster (4); ceca with regular diverticula spaced alternately on the medial and lateral surfaces of the ceca, found in Desmogonius and Barisomum (5); and ceca with regular diverticula found only on the lateral surface of the ceca, found in Cricocephalus (6). This character was not used in constructing the phylogenetic tree, but we include it for future reference.

6) Posterior body projections. The plesiomorphic condition is the absence of posterior body projections in adults, exhibited by Adenogaster, Pronocephalus, Ruicephalus, Metacetabulum, Cetiosaccus, Neopronocephalus, Macravestibulum, and Choanophorus (0). All other pronocephalids exhibit posterior body projections (1).

7) Cephalic collar. The presence of a cephalic collar has been used to distinguish the Pronocephalidae from the Notocotylidae and Microscaphidiidae. The absence of cephalic collars is clearly plesiomorphic (0) and the presence of such collars is apomorphic (1). We have concluded that Parapronocephalum and Notocotyloides, as well as all pronocephalids except for Pseudobarisomum possess cephalic collars. All phylogenetic analyses we performed placed Parapronocephalum and Notocotyloides as members of the Notocotylidae clade, and not as members of the Pronocephalidae. Therefore, the presence of the cephalic collar may be plesiomorphic for the Notocotylidae + Pronocephalidae clade, with independent losses in the Notocotylidae (minus Parapronocephalum and Notocotyloides) and in Pseudobarisomum, or the cephalic collars of Parapronocephalum and Notocotyloides may not be homologous with those of the pronocephalids (in either case, the condition found in Pseudobarisomum is best explained as a secondary loss).

Modifications of the cephalic collar, such as whether or not it is
TABLE I. Data matrix for phylogenetic analysis of Pronocephalidae genera.*

\begin{tabular}{ll} 
DT & 000000000000000000000000000000000000000000000000 \\
NO & 001100120100000000001100000100000100000000000000 \\
PA & 000111120100000000000000000100000100000000000000 \\
NT & 001111020100000000000000000100000100000000000000 \\
AD & 001240111000001001000000000100000100000000000200 \\
PL & 001001111011000001100000000100000100000000000000 \\
HI & 00101111111100001100010000100000100000000000000 \\
IG & 001011111111001111100010000100000100000000000000 \\
RE & 00101111111100000111000100100000100000000000000 \\
PP & 00100111111100001101200000100000100000000000000 \\
PY & 001021111011110001000011001100000100000000011000 \\
CR & 00126111111100012000010110100000100000000001100 \\
PS & 001021011111101002000010001100000100000000001100 \\
BA & 01105111111101002000010001100000100000000001100 \\
CH & 011031111211000001000000000011000100000000000000 \\
DE & 011251111211100001000000000010110100000000000000 \\
DI & 021021111211100001000000000010101100000000000000 \\
PR & 020020111110000001000000000100000000000000010000 \\
RU & 120000111110000001000000000100000111101001110011 \\
CE & 120000111110000001000000000100000211010000010010 \\
ME & 120000111010000001000000000100000211010000010011 \\
NE & 120000101010000001000000000100010111001001110010 \\
MA & 120010111110000001000000000100000111001100010011 \\
CP & 120010111110000001000000000100000111001110010011 \\
\hline
\end{tabular}

* DT = Deuterobaridinae; NO = Notocotylidae; PA = Parapronocephalum; NT $=$ Notocotyloides $; \mathrm{AD}=$ Adenogaster, $\mathrm{PL}=$ Pleurogonius $; \mathrm{HI}=$ Himasomum IG = Iguanacola $; \mathrm{RE}=$ Renigonius $; \mathbf{P P}=$ Parapleurogonius $; \mathbf{P Y}=$ Pyelosomum $\mathbf{C R}=$ Cricocephalus $; \mathbf{P S}=$ Pseudobarisomum $; \mathbf{B A}=$ Barisomum $; \mathbf{C H}=$ Charax icephalus; $\mathrm{DE}=$ Desmogonius; $\mathrm{DI}=$ Diaschistorchis $; \mathrm{PR}=$ Pronocephalus; $\mathrm{RU}$ $=$ Ruicephalus $; \mathrm{CE}=$ Cetiosaccus $; \mathrm{ME}=$ Metacetabulum $; \mathrm{NE}=$ Neopronocephalus; $\mathbf{M A}=$ Macravestibulum; $\mathbf{C P}=$ Choanophorus. $0=$ plesiomorphic state; $1-6=$ derived states.

"continuous" or "interrupted" ventrally, or whether it is "strongly" or "weakly" developed, have been used to distinguish major groups within the family. We have been unable to characterize these modifications consistently due to variations caused by different modes of fixation and preparation and degree of development of individual worms. Future studies based on a large series of new specimens from many species, perhaps using scanning electron microscopy, might provide useful information.

8) Position of ovary with respect to testes. Deuterobarids and paramphistomids exhibit posttesticular ovaries (0). Notocotylids and Parapronocephalum exhibit intertesticular ovaries, a trait exhibited by Pronocephalus (2). All other pronocephalids except Neopronocephalus exhibit pretesticular ovaries (1), while Neopronocephalus exhibits posttesticular ovaries reminiscent of the condition found in deuterobarids (0).

9) Number of genital pores. The plesiomorphic condition is a single genital pore (0), whereas all pronocephalids possess 2 genital pores (1).

10) Number of polar filaments in eggs. Notocotylids and Parapronocephalum exhibit 2 polar egg filaments ( 1 on each pole), a condition also exhibited by most pronocephalids (0). Polar filaments were not observed in Notocotyloides. Adenogaster, some species of Pyelosomum, some species of Pleurogonius, Metacetabulum, and Neopronocephalus lack egg filaments (1), while Charaxicephalus, Desmogonius, Diaschistorchis, and some species of Pyelosomum have multiple polar filaments (2). This character was not used in constructing the phylogenetic tree, but we include it for future reference.

11) Presence or absence of ventral glands. The plesiomorphic condition, exhibited by Adenogaster, most notocotylids, and deuterobaridines, is the possession of glands on the ventral body surface (0). All other pronocephalids lack ventral glands, which we interpret as an apomorphic secondary loss (1). Notocotyloides also reportedly lacks ventral glands, presumably a convergent secondary loss in that group.

12) Shape of posterior end of body. The plesiomorphic condition, 


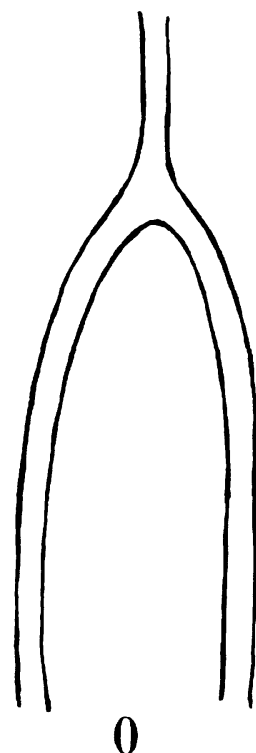

0

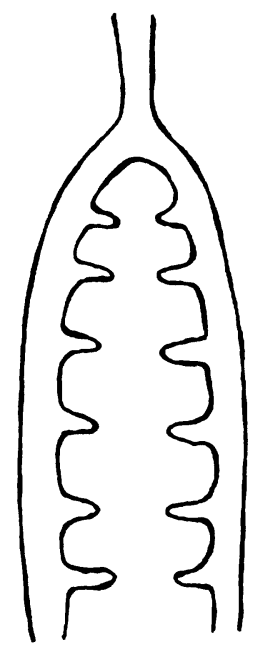

4
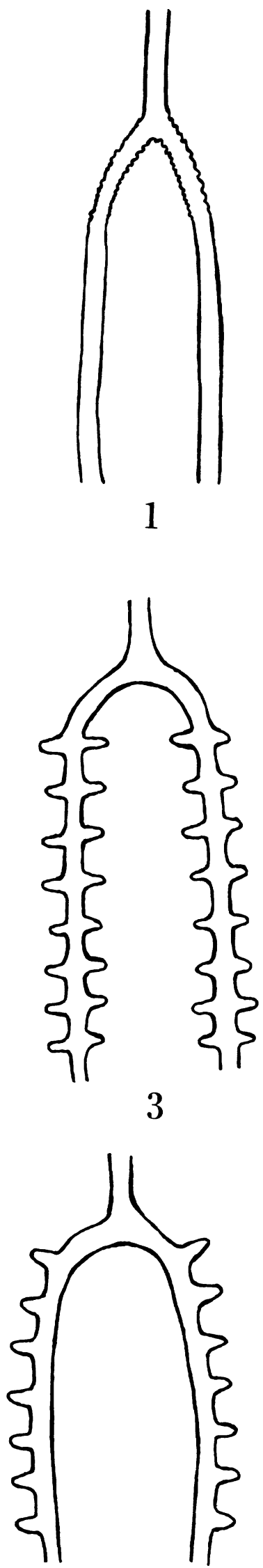

6
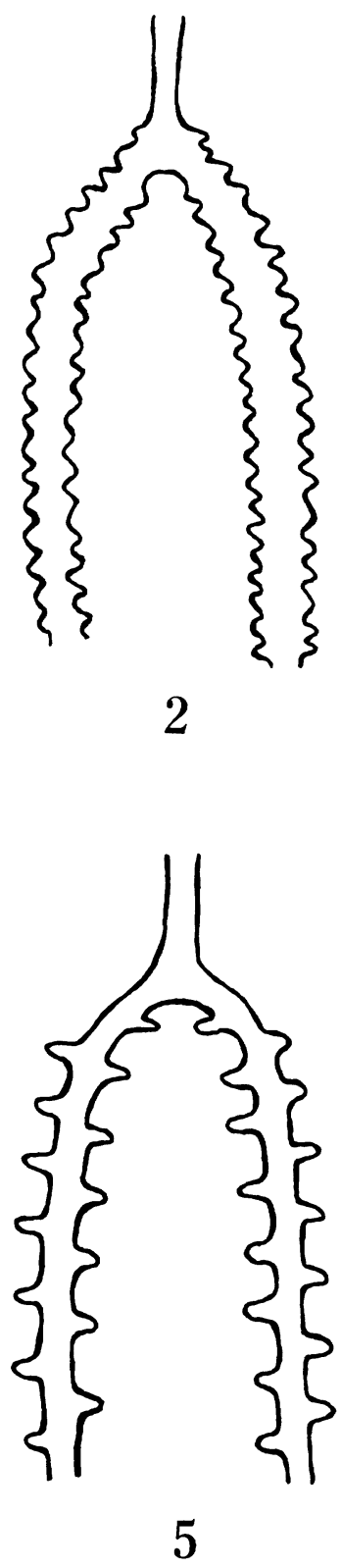
exhibited by Adenogaster, Pronocephalus, Ruicephalus, Metacetabulum, Cetiosaccus, Neopronocephalus, Macravestibulum, and Choanophorus, is rounded posterior ends (some have posterior invaginations of the body as well; see character 36) (0). All other pronocephalids have truncated posterior ends (1).

13) Position of genital pores with respect to ceca. The plesiomorphic condition, exhibited by most pronocephalids, is intercecal genital pores (0). Himasomum, Renigonius, Parapleurogonius, Pyelosomum, Cricocephalus, Barisomum, and Pseudobarisomum, as well as Desmogonius and Diaschistorchis, exhibit extracecal genital pores (1).

14) Body shape. Notocotylids, Parapronocephalum and almost all pronocephalids exhibit slender, elongate bodies (0). Pyelosomum species have bodies that are relatively more plump and rounded (1).

15) Anterior arms of excretory vesicles. Notocotylids, Notocotyloides and Parapronocephalum, and most pronocephalids exhibit arms of the excretory vesicle that are united anteriorly (0). Adenogaster, Iguanacola, Barisomum, and Pseudobarisomum all exhibit separate anterior arms of the excretory system (1).

16) Location of genital pores. In the outgroups and most pronocephalids, the genital pore(s) lie(s) in the anterior $1 / 3$ of the body (0). In Iguanacola, the genital pores are equatorial (1).

17) Cirrus sac shape constrictions. The plesiomorphic condition is a cirrus sac without constrictions (0). Iguanacola and Cricocephalus have a cirrus sac with a constriction in the middle (1).

18) Cirrus sac shape. Notocotylids, Notocotyloides and Parapronocephalum, and Renigonius possess narrow, elongate cirrus sacs (0). Most other pronocephalids possess relatively short and spherical, but weakly muscled, cirrus sacs (1), except or Cricocephalus, Barisomum, and Pseudobarisomum, which possess relatively short and spherical, but strongly muscled, cirrus sacs (2).

19) Relative length of esophagus. The plesiomorphic condition is relatively short esophagi (0). Members of Pleurogonius, Iguanacola, Renigonius, and Parapleurogonius possess relatively long esophagi (1).

20) Development of eggs. The plesiomorphic condition is nonembryonated eggs (0). Renigonius has embryonated eggs (1).

21) Position of ceca with respect to testes. The plesiomorphic condition is ceca extending to near the posterior end of the body (0). $R e$ nigonius and Parapleurogonius possess ceca that terminate at the anterior margins of the testes (1).

22) Internal seminal vesicle. Deuterobaridines, Notocotyloides and Parapronocephalum, and almost all pronocephalids lack a true internal seminal vesicle $(0)$. Notocotylids possess relatively large internal seminal vesicles (1). Parapleurogonius possesses a small internal seminal vesicle (2).

23) Extent of uterine loops with respect to ceca. The plesiomorphic condition is intercecal uterine loops (0). Cecal and extracecal uterine loops (1) occur in Himasomum, Iguanacola, Pyelosomum, Cricocephalus, Barisomum, and Pseudobarisomum. cecal and extracecal uterine loops occur in some other species of Pleurogonius, but we code Pleurogonius as plesiomorphic for the trait pending a more detailed analysis of the genus.

24) Cecal configuration. The plesiomorphic condition is ceca that extend posteriorly in essentially a straight line (0). Four species of Pyelosomum exhibit sinuous ceca (1), and the other 2 species exhibit serpentine ceca (2). The transformation series for this character was determined as a result of a species-level analysis of Pyelosomum (Pérez Ponce de Léon and Brooks, 1995); in this study, Pyelosomum is coded as (1).

25) Position of genital pore with respect to cecal bifurcation. The plesiomorphic condition is genital pores positioned immediately posterior to the cecal bifurcation (0). Renigonius and Cricocephalus exhibit prebifurcal genital pores (1).

26) Metraterm structure. The plesiomorphic condition is "simple," i.e., relatively short and straight, metraterms. Cricocephalus exhibits a very long metraterm with 2 prominent muscular and glandular dilatations (1).

27) Orientation of cirrus sac. The plesiomorphic condition is cirrus sacs oriented longitudinally in the body (0). Pyelosomum, Barisomum, and Pseudobarisomum exhibit transverse cirrus sacs (1).

28) Testes condition. The plesiomorphic condition is paired entire testes (0). Charaxicephalus, Desmogonius, and Diaschistorchis have fragmented testes (1).

29) Esophageal bulb. Notocotylids, Notocotyloides and Parapronocephalum, and most pronocephalids lack any muscular swelling at the juncture of the cecal bifurcation, called an esophageal bulb (0). Charaxicephalus, Desmogonius, and Diaschistorchis exhibit esophageal bulbs (1), which would appear to be convergent with similar structures found in many paramphistomids and microscaphidiids.

30) External seminal vesicle structure. The plesiomorphic condition is external seminal vesicles with smooth walls (0). In Charaxicephalus the external seminal vesicle has constrictions (1).

31) External seminal vesicle shape. The plesiomorphic condition is relatively short and winding external seminal vesicles (0). Desmogonius and Diaschistorchis exhibit long and straight external seminal vesicles (1).

32) Position of vitellaria with respect to testes. The plesiomorphic condition is pretesticular vitellaria (0). In Neopronocephalus and Desmogonius the vitellaria are posttesticular (1).

33) Position of testes with respect to ceca. The plesiomorphic condition is testes lying dorsal to the plane of the cecal, whether they are extracecal or intercecal (0). In Diaschistorchis, the testes lie ventral to the ceca (1).

34) Arrangement of testes. Deuterobaridines, some microscaphidiids, and some paramphistomids exhibit obliquely arranged testes, which we code as plesiomorphic (0); Pronocephalus also exhibits this condition. Notocotylids, Parapronocephalum, and almost all pronocephalids have symmetrically arranged testes (1), while Cetiosaccus and Metacetabulum exhibit tandem testes (2).

35) Relative length of ceca. The plesiomorphic condition is relatively long ceca extending at least to within 1 testis diameter of the posterior end of the body (0). Ruicephalus, Metacetabulum, Cetiosaccus, Neopronocephalus, Macravestibulum, and Choanophorus have relatively short ceca that terminate more than 1 testis diameter from the posterior end (1).

36) Posterior vestibule. The plesiomorphic condition is posterior ends terminating simply with a terminal or dorso-terminal excretory pore (0). Ruicephalus, Metacetabulum, Cetiosaccus, Neopronocephalus, Macravestibulum, and Choanophorus possess prominent invaginations of the posterior end of the body, which has been called the "posterior vestibule" (1).

37) Position of vitelline follicles with respect to the ovary. The plesiomorphic condition is preovarian vitelline follicles (0). Ruicephalus exhibits postovarian vitelline follicles (1).

38) Relative size of the excretory vesicle. The plesiomorphic condition is a relatively small excretory vesicle that is often difficult to see in preserved material (0). Cetiosaccus and Metacetabulum, by contrast, exhibit very large and prominent excretory vesicles (1).

39) Thickening of esophageal walls. The plesiomorphic condition is relatively thin-walled esophagi (0). Ruicephalus, Metacetabulum, Cetiosaccus, Neopronocephalus, Macravestibulum, and Choanophorus all possess thickened esophageal walls (1).

40) Posterior digitiform processes. The plesiomorphic condition is no digitiform processes associated with the posterior end of the body (0). Macravestibulum and Choanophorus exhibit such processes (1).

41) Copulatory pouch. The plesiomorphic condition is genital pore(s) opening directly at the surface of the worm (0). In Choanophorus the genital pores open into a copulatory pouch (1).

42) Extent of uterine loops with respect to ovary and testes. The

FIGURE 1. Diagrammatic representation of the diversity of cecal morphologies for pronocephalid digeneans. 0 , Smooth-walled throughout their entire length; 1 , with irregular diverticula in anterior portion; 2 , with irregular diverticula throughout their length; 3 , with regular diverticula paired on medial and lateral surfaces of ceca; 4 , with regular diverticula only on medial surface of ceca; 5 , with regular diverticula alternating on medial and lateral surfaces of ceca; 6 , with regular diverticula only on lateral surface of ceca. 0 is the plesiomorphic condition; all other numbers are arbitrary and do not represent a linear transformation series. 


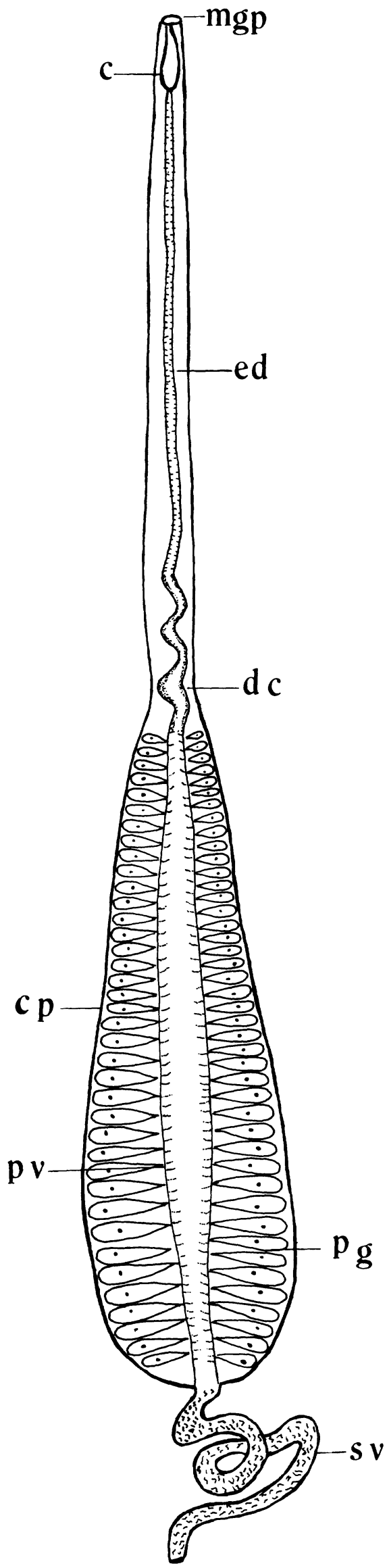

plesiomorphic condition is no uterine loops between the testes and ovary (0). Pronocephalus and Ruicephalus exhibit uterine loops between the testes and ovary (1).

43) Relative number of vitelline follicles. The plesiomorphic condition is numerous vitelline follicles in each vitellarium (0). In Ruicephalus and Neopronocephalus there are very few follicles in each vitellarium (1).

44) Relative size of cirrus sac. The plesiomorphic condition is relatively long cirrus sacs (0). Pyelosomum, Pronocephalus, Ruicephalus, Metacetabulum, Cetiosaccus, Neopronocephalus, Macravestibulum, Choanophorus possess very short cirrus sacs (1).

45) Relative size of excretory pore. The plesiomorphic condition is very small excretory pores, which are sometimes difficult to find in preserved material (0). Pyelosomum, Cricocephalus, Barisomum, and Pseudobarisomum all possess prominent excretory pores (1).

46) Ductus Caballeroi. The plesiomorphic condition is a vesiculate pars prostatica joined closely to the ejaculatory duct (0). In Adenogaster, Cricocephalus, Barisomum, and Pseudobarisomum, the pars prostatica is separated from, and connected to, the ejaculatory duct by a distinct winding tube, which we are calling the ductus Caballeroi, in honor of the late Dr. Eduardo Caballero y Caballero (Fig. 2). The ductus Caballeroi has 2 forms in the Pronocephalidae. In Adenogaster, it is long and relatively straight (1), whereas in Cricocephalus, Barisomum, and Pseudobarisomum, it is very short and coiled (2).

47) Position of excretory pore. The plesiomorphic condition is excretory pores that open dorsally near the posterior end of the body (0). In Ruicephalus, Metacetabulum, Cetiosaccus, Neopronocephalus, Macravestibulum, and Choanophorus the excretory pores open at the posterior end of the body (1).

\section{RESULTS}

All combinations of PAUP options listed above produced the same 6 equally parsimonious trees with consistency indices of $70.1 \%$ ( 77 changes for 53 possible apomorphies) for the Pronocephalidae and the Notocotylidae + Notocotyloides and Parapronocephalum, and $77.8 \%$ for the Pronocephalidae alone (63 changes for 49 possible apomorphies). The trees differ only in the placement of Pleurogonius, Renigonius + Parapleurogonius Iguanacola, and Himasomum. We have been unable to find a synapomorphy for Pleurogonius, suggesting that it is probably paraphyletic, and this may account for the ambiguity in the analysis. Adding characters 5 and 10 and treating all members of Pleurogonius as plesiomorphic for both characters lowers the consistency index to approximately $66 \%$ and produces 32 equally parsimonious trees, 6 of which are those found when the 2 characters are excluded. When character 5 is included and 10 excluded, the same 32 equally parsimonious trees result, with a consistency index of approximately $69 \%$. Excluding character 5 and including character 10 produces 12 equally parsimonious trees, 6 of which are those found when the 2 characters are excluded, with a consistency index of approximately $68 \%$.

Despite the ambiguity produced by Pleurogonius, our analysis supports a more informative and stable classification than previous treatments of the family. The relative relationships among Adenogaster, Pronocephalus, Ruicephalus, Neopronocephalus, Macravestibulum, Choanophorus, Metacetabulum, Cetiosaccus, Charaxicephalus, Desmogonius, Diaschistorchis, Pyelosomum, Cricocephalus, Barisomum, and Pseudobarisomum are identical

FIGURE 2. Diagrammatic representation of the components of the male genitalia of Pronocephalidae. mgp, Male genital pore; c, cirrus; ed, ejaculatory duct; dc, ductus Caballeroi; $\mathrm{cp}$, cirrus pouch; pv, prostatic vesicle; $p g$, prostatic glands; sv, seminal vesicle. 


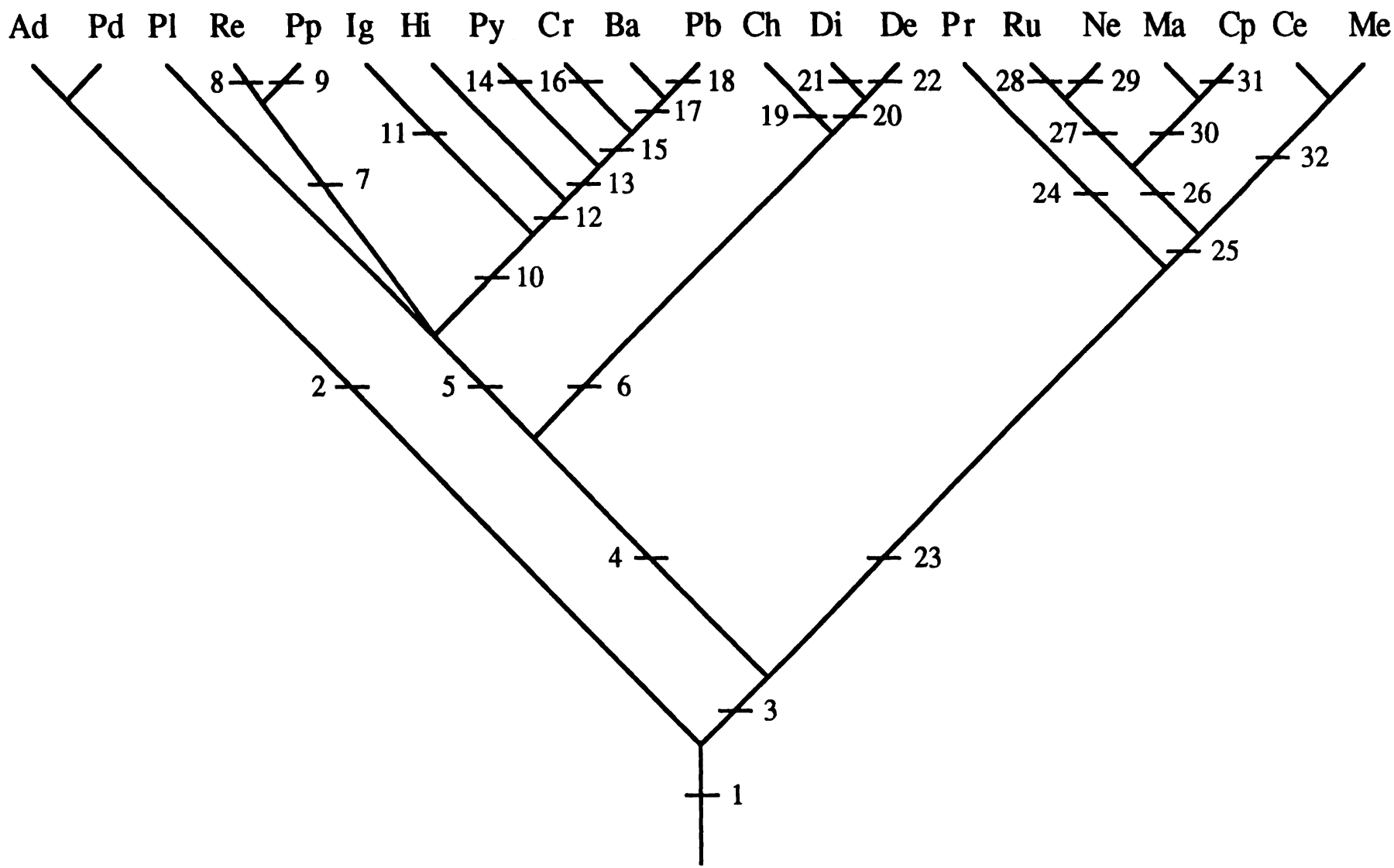

FIGURE 3. Consensus tree depicting the proposed phylogenetic relationships among $\mathbf{2 0}$ genera of pronocephalid digeneans (Paradenogaster added as sister group of Adenogaster for host and geographic comparisons). AD, Adenogaster; PD, Paradenogaster; PL, Pleurogonius; HI, Himasomum; IG, Iguanacola; RE, Renigonius; PP, Parapleurogonius; PY, Pyelosomum; CR, Cricocephalus; PS, Pseudobarisomum; BA, Barisomum; CH, Charaxicephalus; DE, Desmogonius; DI, Diaschistorchis; PR, Pronocephalus; RU, Ruicephalus; CE, Cetiosaccus; ME, Metacetabulum; NE, Neopronocephalus; MA, Macravestibulum; CP, Choanophorus. Numbers accompanying slash marks on tree indicate apomorphic traits (character number followed by state in parentheses; ${ }^{*}$, homoplasious state) supporting each branch as follows: 1: 3(1), 7(1), 8(1), 9(1), 18(1); 2: 4(2)*, 15(1)*, 46(2); 3: $11(1)$; 4: 6(1), 12(1); 5: 19(1); 6: 2(1), 28(0)*, 29(1); 7: 13(1)*, 21(1); 8: 18(0)* 20(1), 25(1)*; 9: 22(2); 10: 23(1); 11: 15(1)*, 16(1), 17(1); 12: 13(1)*; 13: 27(1), 45(1); 14: 14(1), 24(1), 44(1)*; 15: 18(2), 46(1); 16: 4(2)*, 25(1)*, 26(1), 27(0)*; 17: 15(1)*; 18: 7(0)*; 19: 30(1); 20: 13(1)*, 30(1); 21: 33(1); 22: 4(2)*, 32(1)*, 23: 2(3), 3(0)* 44(1)*; 24: 34(0)*; 25: 1(1), 35(1), 36(1), 47(1); 26: 39(1); 27: 42(1), 43(1); 28: 37(1); 29: $8(0)^{*}, 32(1)^{*} ; 30: 40(1) ; 31: 41(1) ; 32: 34(2), 38(1)$.

in all 6 trees. In 4 of the 6 trees, Himasomum is the sister group of the Pyelosomum clade and Pleurogonius is the sister group of Renigonius + Parapleurogonius, Iguanacola, Himasomum, and the Pyelosomum clade. The phylogenetic tree in Figure 3 is the Adams and the $50 \%$ majority-rule consensus tree topology and reflects the majority placements of Himasomum as the sister group of the Pyelosomum clade, and Pleurogonius as the sister group of Renigonius + Parapleurogonius, Iguanacola, Himasomum, and the Pyelosomum clade.

\section{DISCUSSION}

The monophyly of the Pronocephalidae Looss, 1902, is supported based on the following synapomorphies identified in this study: intercecal testes, presence of a cephalic collar, pretesticular ovaries, 2 genital pores, and relatively short and spherical, but weakly muscled, cirrus sacs. Within the family, three major clades have been identified. Two of them are sister groups, and subfamilial names have been proposed for them previously. The Charaxicephalinae Price, 1931 is the oldest subfamilial name associated with the clade containing Charaxicephalus Looss,
1901 [=Charaxicephaloides Groschaft and Tenora, 1978], Desmogonius Stephens, 1911, Diaschistorchis Johnston, 1913 [=Wilderia Pratt, 1914, Synechorchis Braker, 1922], Pleurogonius Looss, 1901 [=Mediporus Ozaki, 1936, Epibathra Looss, 1902, Glyphicephalus Looss, 1901 in part], Renigonius Mehra, 1939, Parapleurogonius Sullivan, 1977, Iguanacola Gilbert, 1938, Himasomum Linton, 1910, Pyelosomum Looss, 1899 [=Epibathra Looss, 1902, Astrorchis Poche, 1926, and Myosaccus Gilbert, 1938], Cricocephalus Looss, 1899 [=Neocricocephalus Gupta, 1962], Barisomum Linton, 1910, and Pseudobarisomum Siddiqi and Cable, 1960. The monophyly of this clade is supported by the synapomorphies of posterior body projections and truncated posterior ends. The Pronocephalinae Looss, 1902 is the oldest subfamilial name associated with the clade containing Pronocephalus Looss, 1899, Cetiosaccus Gilbert, 1938, Metacetabulum Teixeira de Freitas and Lent, 1938, Ruicephalus Skrjabin, 1955, Neopronocephalus Mehra, 1932, Macravestibulum Mackin, 1930, and Choanophorus Caballero, 1942. The monophyly of this clade is supported by the synapomorphies of testes located in posterior $1 / 3$ of body, but some distance from the posterior end, intercecal testes and very short 


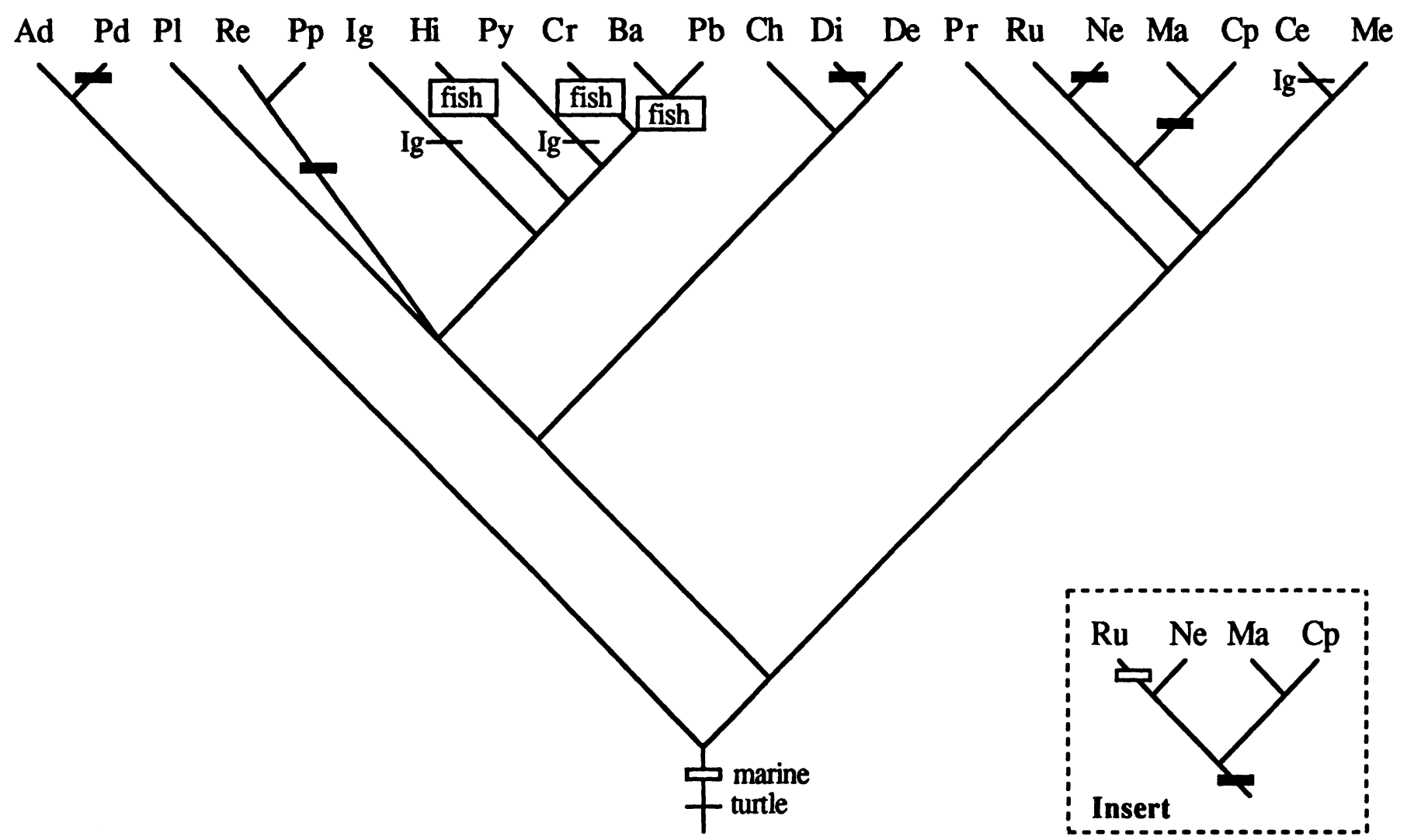

FIGURE 4. Definitive host group (turtles, marine fish, marine iguanas) and primary habitat (marine/estuarine, freshwater) optimized onto phylogenetic tree for pronocephalid digeneans.

cirrus sacs. The third, containing only Adenogaster, is the sister group of the other 2 . Its monophyly is supported by the synapomorphies of Mehlis' gland located laterally to the ovary, separate anterior arms of excretory system and having a long and straight ductus Caballeroi. To our knowledge, no subfamilial name has ever been proposed for Adenogaster, so we propose the following:

\section{Adenogasterinae n. subfam.}

Diagnosis: Digenea; Paramphistomiformes; Pronocephalidae. Body slender, elongate. Posterior end rounded, projections lacking. Glands present on ventral surface. Oral sucker relatively small; esophagus relatively short, bulb lacking; ceca smooth-walled throughout their length or with regular diverticula found only on medial surface of, extending posttesticularly to near posterior end of body. Male genital pore intercecal, sinistral, in anterior $1 / 3$ of body, immediately posterior to cecal bifurcation; cirrus sac relatively long and spherical, weakly muscled, containing prostatic complex, long and straight ductus Caballeroi, ejaculatory duct, and relatively short cirrus; external seminal vesicle short, winding. Testes extracecal, symmetrical, near posterior end of body, dorsal to cecal plane, with irregular margins. Ovary immediately pretesticular, intercecal, dextral, spherical, or with irregular margins; Mehlis' gland located laterally to ovary. Uterus with transverse intercecal coils between level of anterior margin of testes and midbody; metraterm approximately half length of cirrus sac, surrounded by gland cells; female genital pore intercecal, immediately posterior to male genital pore. Vitellaria follicular, preovarian and pretesticular, in 2 lateral extracecal bands extending from the level of the anterior margin of the testes to midbody or more restricted; follicles relatively large or very small. Eggs with single filament at each pole or with single knob at each pole. Excretory vesicle V-shaped with separate arms; pore opening dorsally near posterior end of body. Intestinal parasites of marine and freshwater turtles.
Cosmopolitan. Type genus: Adenogaster Looss, 1901 [=Paradenogaster Fischthal and Kuntz, 1975, Cortinasoma Oshmarin and Zharikova, 1984].

Our study also indicates that $H$. candidulum Linton, 1910 and $G$. lobatus Looss, 1901 form a group diagnosably distinct from Pleurogonius and Barisomum. In recognizing Himasomum, we propose the following amended diagnosis:

\section{Himasomum Linton, 1910}

Amended diagnosis: Digenea; Paramphistomiformes; Pronocephalidae; Charaxicephalinae. Body slender, elongate. Posterior end rounded, projections lacking. Oral sucker relatively small, bulb lacking; esophagus relatively short; ceca irregularly diverticulate near cecal bifurcation, extending posttesticularly to near posterior end of body. Male genital pore extracecal, sinistral, immediately posterior to level of cecal bifurcation; cirrus sac relatively large, containing prostatic complex, ejaculatory duct, and relatively short cirrus; external seminal vesicle winding; testes extracecal, near posterior end of body, dorsal to cecal plane, with irregular margins. Ovary immediately pretesticular, intercecal, dextral, spherical, or with irregular margins; Mehlis' gland postovarian; uterus with transverse cecal and intercecal coils between level of anterior margin of testes and midbody; metraterm approximately half length of cirrus sac, surrounded by gland cells; female genital pore extracecal, immediately posterior to male genital pore. Vitellaria follicular, pretesticular and preovarian, in 2 lateral extracecal bands extending from the level of the anterior margin of the testes to midbody. Eggs with single filament at each pole. Excretory vesicle V-shaped with anterior arms united at mid-esophageal level; pore opening dorsally near posterior end of body. Intestinal parasites of marine turtles and fishes. Cosmopolitan. Type species: $\boldsymbol{H}$. candidulus Linton, 1910 [=B. candidulus: Price, 1937; $P$. candidulus: Ruiz, 1946; P. candidulus: Manter, 1947; G. candidulus: Siddiqi and Cable, 1960; Glyphicephalus macintoshi Siddiqi and Cable 

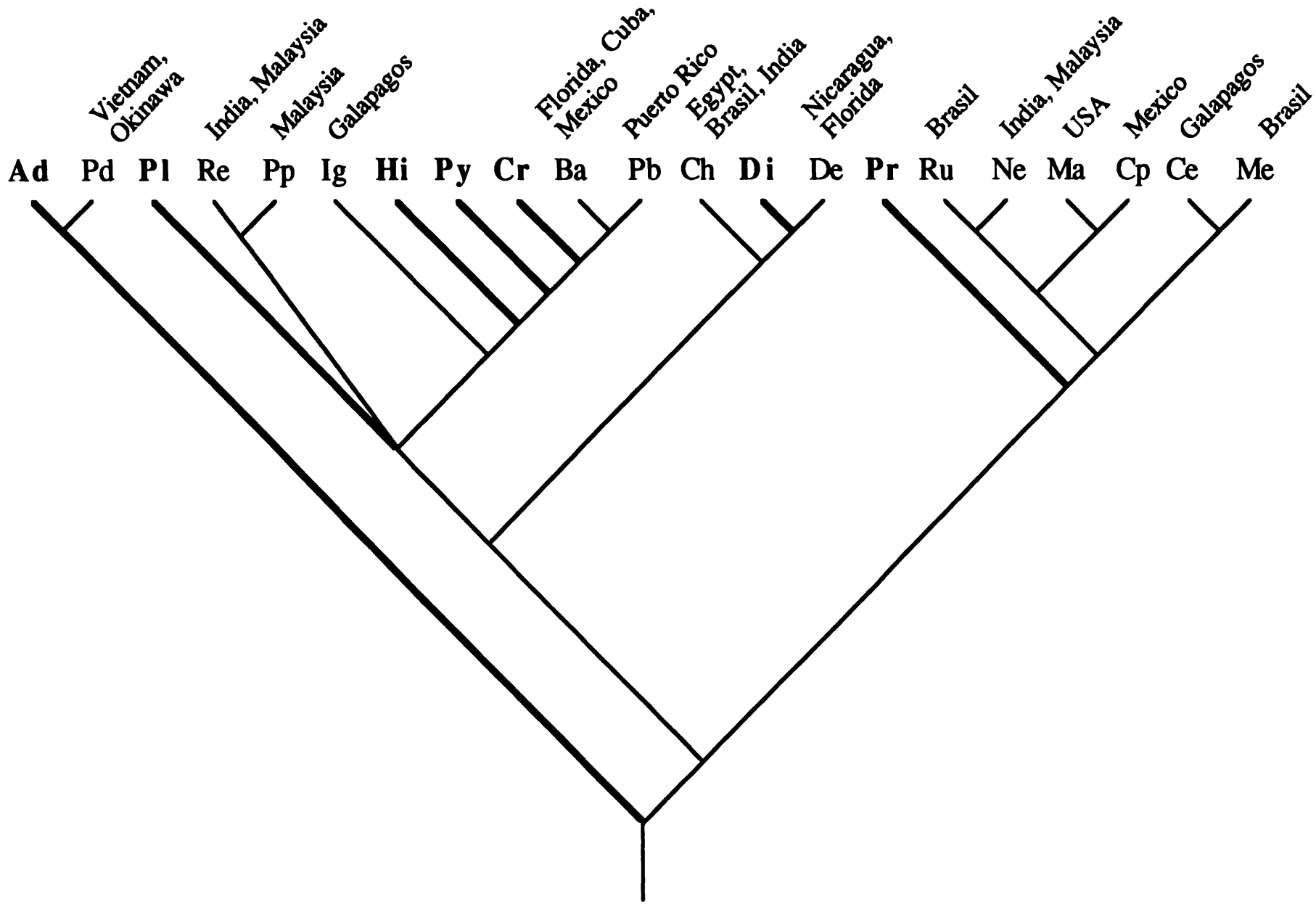

FIGURE 5. General geographic distributions (cosmopolitan or more restricted) depicted on phylogenetic tree for pronocephalid digeneans.

1960] in Pomacanthus arcuatus (type host) and Angelichthys isabelita from the United States (Florida) (type locality), Puerto Rico, and Jamaica. Other species: $H$. lobatus (Looss, 1901) comb. n. [ $=G$. lobatus Looss, 1901; G. lobatus: Looss, 1901; G. lobatus: Oguro, 1936; P. lobatus: Ruiz, 1946; P. lobatus: Caballero et al., 1955] in C. mydas (type host), Eretmochelys squamosa, and Lepidochelys olivacea from Egypt (type locality), Panama, Philippines (Palao Islands), Mexico (Oaxaca), United States (Florida), Puerto Rico, and Jamaica.

Brooks and McLennan (1993a, 1993b) presented evidence that parasitic platyhelminths did not exhibit unusually high levels of character loss and homoplasy, indicative of unusual degrees of evolutionary simplification or plasticity. Our study supports their findings. The consistency index value of $70.1 \%$ for the entire tree compares favorably with the values reported for phylogenetic analysis of morphological data for other digenean groups $\mathbf{7 1 . 7 \%}$ for the overall data base: see Brooks and McLennan, 1993a, 1993b). In addition, of 63 character changes for Pronocephalidae, 5 (8\%) are evolutionary losses; Brooks and McLennan (1993a, 1993b) reported $12 \%$ for digeneans as a whole. Characters that show evolutionary loss in this study are adult nonreproductive characters (loss of the cephalic collar, of the ventral glands, and of the connection between the anterior arms of the excretory vesicle). Among digeneans, Brooks and McLennan (1993a, 1993b) reported 23\% of the male reproductive characters, $3 \%$ of the female reproductive characters, $14 \%$ of the adult nonreproductive characters, and $13 \%$ of the larval characters were lost at least once. Three of the 5 losses (60\%) in our study are homoplasious; Brooks and McLennan (1993a, 1993b) listed 55\%. Brooks and McLennan (1993a, 1993b) reported that $30 \%$ of male reproductive characters, $35 \%$ of female reproductive characters, $34 \%$ of adult nonreproductive characters, and $9 \%$ of larval characters exhibited homoplasy. Of the 63 character changes for Pronocephalidae, 14 are homoplasious. These include 4-7 changes in male reproductive characters ( 30 $50 \%), 3-6$ changes in female reproductive characters (20-40\%), and 4 changes in adult nonreproductive characters (30\%). The range in numbers for male and female characters is due to homoplasy in characters involving the genital pores, which include both male and female components.

Optimizing-definitive host type and general habitat (marine/ estuarine or freshwater) onto the phylogenetic tree (Fig. 4) suggests that pronocephalids are primitively, as well as predominantly, parasites of marine turtles. The evidence supports 4 shifts from marine to freshwater turtles (Cortinasoma, Renigonius + Parapleurogonius, Neopronocephalus, Macravestibulum + Choanophorus) or 3 shifts from marine to freshwater turtles (Cortinasoma, Renigonius + Parapleurogonius, Neopronocephalus + Ruicephalus + Macravestibulum + Choanophorus) and 1 secondary return to marine turtles (Ruicephalus). The habitat shifts also involve host switching, as there is no close phylogenetic relationship among the marine and fresh- 
water chelonian hosts for pronocephalids; aside from being turtles, what the hosts have in common is herbivorous feeding habits. Published host lists for pronocephalids suggest extensive host switching among marine turtles as well, but we require species level phylogenetic trees to make better estimates of the nature and extent of those switches. There is evidence of 3 separate host shifts from marine turtles to the Galapagos marine iguana Amblyrhynchus cristatus (Iguanacola, Pyelosomum amblyrhynchi, and Cetiosaccus), and 3 shifts from marine turtles to marine fish, primarily the French angelfish Pomacanthus arcuatus ( $H$. candidulum [also found in Angelichthys isabelita], $C$. albus, and the common ancestor of Barisomum + Pseudobarisomum). In no case have we found evidence supporting a switch from marine to freshwater (or freshwater to marine) coinciding with a host switch from chelonian to non-chelonian definitive hosts.

Figure 5 depicts general geographic distribution patterns for the pronocephalid taxa considered herein. Without a species level phylogenetic tree, we cannot draw many specific conclusions. It is evident, however, that the biogeographic history of the pronocephalids is complex, suggesting a mixture of dispersal and vicariance played out over a significant period of time.

This study represents an important preliminary step in the quest to understand the evolution of the helminth communities of marine turtles. The glimpse provided by this study indicates that history is likely to be complex and fascinating. In the future, we need better resolution of the pronocephalid genera that contain more than 2 species, such as Pyelosomum (see Pérez Ponce de León and Brooks, 1995),Cricocephalus, Barisomum, Diaschistorchis, Neopronocephalus, Macravestibulum, and, in particular, Pleurogonius. We also need phylogenetic hypotheses for other species-rich helminth groups inhabiting marine turtles, such as the microscaphidiid and spirorchid digeneans.

\section{ACKNOWLEDGMENTS}

Funding for this study was provided by DGAPA-UNAM through a fellowship to G.P. for research at the University of Toronto, and the Natural Sciences and Engineering Research Council of Canada, through NSERC operating grant A7696 to D.R.B. We thank to Mary H. Pritchard and Skip Sterner, Division of Parasitology, University of Nebraska State Museum and J. Ralph Lichtenfels and Patricia Pilitt, United States National Helminthological Collection for specimens; and Deborah A. McLennan for graphics.

\section{LITERATURE CITED}

Brooks, D. R., S. M. BANDONI, C. A. MACDONALD, AND R. T. O'Grady. 1989. Aspects of the phylogeny of the Trematoda Rudolphi, 1808 (Platyhelminthes: Cercomeria). Canadian Journal of Zoology 67: 2609-2624.

- R. T. O'Grady, AND D. R. Glen. 1985. Phylogenetic analysis of the Digenea (Platyhelminthes: Cercomeria) with comments on their adaptive radiation. Canadian Journal of Zoology 63: 41 1-443.

-, AND D. A. MCLenNaN. 1991. Phylogeny, ecology and behavior: A research program in comparative biology. University of Chicago Press, Chicago, Illinois, $434 \mathrm{p}$.

- AND - 1993a. Parascript: Parasites and the language of evolution. Smithsonian Institution Press, Washington, D.C., $429 \mathrm{p}$.

$\longrightarrow$, AND - 1993b. Macroevolutionary trends in the morphological diversification among the parasitic flatworms (Platyhelminthes: Cercomeria). Evolution 47: 495-509.
Caballero y C., E. 1942. Trematodos de las tortugas de Mexico. II. Descripción de un nuevo genero de la familia Pronocephalidae Looss, 1902 y descripción de una nueva especie del genero Octangioides Price, 1937. Anales del Instituto de Biología de la Universidad Nacional Autónoma de México 12: 81-90.

- M. C. Zerecero, AND R. G. Grocotr. 1955. Helmintos de la República de Panamá. XI. Trematodos de Chelone mydas (L.) tortuga marina comestible del oceano Pacifico del norte. 2a parte. Anales del Instituto de Biología de la Universidad Nacional Autónoma de México 26: 149-191.

- AND R. E. KUNTZ. 1975. Some trematodes of amphibians and reptiles from Taiwan. Proceedings of the Helminthological Society of Washington 42: 1-13.

FukUI, T. 1929. Studies on Japanese amphistomatous parasites, with revision of the group. Japanese Journal of Zoology 2: 91-102.

. 1933. Teloporia (Tremat.) $=$ Opisthoporus. Zoologisches Anzeiger 103: 332-333.

GILBERT, P. T. 1938. Three new trematodes from the Galapagos marine iguana Amblyrhynchus cristatus. Memoirs of the Allen Hancock Pacific Expedition 2: 91-103.

Groschaft, J., AND F. TenORA. 1978. Charaxicephaloides polyorchis gen. nov., sp. nov. (Trematoda: Charaxicephalinae) from Chelonia mydas mydas (Testudinata) in Cuba. Vestnik Ceskoslovenske Spolecnosti Zoologicke 42: 108-111.

- AND - 1981. Reorganization of suborder Notocotylata (Trematoda). Acta Scientiarum Naturalium Academiae Scientiarum Bohemoslovacae, Brno 15: 1-46.

GuPTA, S. P. 1962. On two new trematodes from the intestine of the marine turtle, Chelone mydas, from the Caribbean Sea. Indian Journal of Helminthology 14: 71-76.

HenNig, W. 1966. Phylogenetic systematics. University of Illinois Press, Urbana, Illinois, 263 p.

Looss, A. 1901. Notizen zur Helminthologie Aegyptens IV. Über Trematoden aus Seeschildkröten der aegyptischen Küsten. Centralblatt fur Bakteriologie 30: 555-569, 618-625.

Maccallum, G. A. 1921. Studies in helminthology Part 1. Trematodes. Zoopathologica 1: 137-284.

MACKIN, J. G. 1930. A new pronocephalid monostome from a freshwater turtle. Journal of Parasitology 17: 25-29.

MANTER, H. W. 1947. The digenetic trematodes of Tortugas, Florida. American Midland Naturalist 38: 257-416.

Mehra, H. R. 1932. Classification de la famille des Pronocephalidae Looss. Annales de Parasitologie Humaine et Comparee 10: 233239.

OGURO, Y. 1936. Einige neue und bekannte Pronocephaliden aus japonischen Seeschildkroten. Journal of Science of the Hiroshima University, Series B, Division 1 5: 1-28.

Oshmarin, P. G., AND T. I. Zharikova. 1984. [A new trematode species and genus, Cortinasoma acadiae n.g. n. sp. (Pronocephalata, Pronocephalidae), parasitic in freshwater turtles from Vietnam]. In Parazity Zhivotnykh i Rastenii, Akademyia Nauk SSR, Dal'nevostochnyi Nauchnyi Tsentr, Biologo-pochvennyi Institut Vladivostok, p. 44-50. [In Russian.]

Pérez Ponce de León, G., AND D. R. Brooks. 1995. Phylogenetic relationships among the species of Pyelosomum Looss, 1899 (Digenea: Pronocephalidae). Journal of Parasitology (in press).

Pérez Vigueras, I. 1955. Contribución al conocimiento de la fauna helmintologica cubana. Memorias de la Sociedad Cubana de la Historia Natural 22: 21-71.

Price, E. W. 1931. Redescription of two species of trematode worms from the MacCallum collection with a note on the family Pronocephalidae. Proceedings of the United States National Museum 78: $1-10$.

RAO, S. B. 1975. Studies on the trematode parasites of turtles from India. Further contribution to our knowledge of the family Pronocephalidae Looss, 1902. Rivista di Parassitologia 36: 137-151.

RoHDE, K. 1962. A new trematode Diaschistorchis multitesticularis sp. n. from a Malayan tortoise Hieremys annandalei (Boulenger). Journal of Parasitology 48: 296-297.

RuIz, J. M. 1946. Pronocephalidae (Trematoda). Estudos des especies brasileiros e revisao da familia. Memorias do Instituto Butantan 19: 249-372. 
SiddiQI, A. H. 1965. Two new trematodes from freshwater turtles in India. Journal of Helminthology 39: 277-280.

- AND R. M. CABLE. 1960. Digenetic trematodes of marine fishes of Puerto Rico. Scientific survey of Puerto Rico and Virgin Islands 17: 257-369.

SwofFord, D. 1993. Phylogenetic analysis using parsimony. Version 3.1.1. Illinois Natural History Survey, Urbana, Illinois.

TeixeIrA De Freitas, J. F., AND H. Lent. 1938. Sobre alguns trematodeos parasitos de Chelone mydas (L.), principalmente Paramphistomoidea. Memorias do Instituto Oswaldo Cruz 33: 79-87.

WILEY, E. O. 1981. Phylogenetics: The theory and practice of phy- logenetic systematics. Wiley-Interscience, New York, New York, $439 \mathrm{p}$.

, D. Siegel-Causey, D. R. Brooks, ANd V. A. FunK. 1991. The compleat cladist: A primer of phylogenetic procedures. University of Kansas Museum of Natural History Press, Lawrence, Kansas, $158 \mathrm{pp}$.

Yamaguti, S. 1958. Systema Helminthum, Vol. I. The digenetic trematodes of vertebrates. Interscience Publishers, Inc., New York, New York, $1,575 \mathrm{p}$.

. 1971. Digenetic trematodes of vertebrates. Keigaku Publishing Company, Tokyo, Japan, 1,074 p. 